Romanticism on the Net

An open access journal devoted to British Romantic literature

Ro Romanticism on the Net

\title{
Settling at Keswick: Affective Bioregionalism in Southey Country
}

\section{Joanna E. Taylor}

Numéro 68-69, spring-fall 2017

Robert Southey

URI : https://id.erudit.org/iderudit/1070625ar

DOI : https://doi.org/10.7202/1070625ar

Aller au sommaire du numéro

Éditeur(s)

Université de Montréal

ISSN

2563-2582 (numérique)

Découvrir la revue

Citer cet article

Taylor, J. E. (2017). Settling at Keswick: Affective Bioregionalism in Southey Country. Romanticism on the Net, (68-69). https://doi.org/10.7202/1070625ar
Résumé de l'article

This article explores how Keswick, a market town in the northern Lake District, became the locus for Southey's development of his own poetic landscape. In particular, it argues that Southey's representations of Keswick-the most significant tourist destination in the Romantic-era Lake

District-counterpointed the development in the south Lakes of Wordsworthshire, the area around Grasmere and Ambleside that Wordsworth was explicitly claiming as his poetic ground. But, this article suggests, whereas the cultural-geographical legacies of Wordsworthshire were based on texts that advocated what Keats termed the "egotistical sublime," Southey Country prioritised social interaction. This article explores how Southey's Lake District was based on texts that emphasised bonds between family and friends that were firmly tied to key locations, particularly his home at Greta Hall and the waterfall at Lodore. In doing so, this article posits a new reading of Lakeland Romanticism that situates this Lake Poet at the centre of a trans-historical community. 


\title{
Ron
}

Romanticism on the Net

\section{Settling at Keswick: Affective Bioregionalism in Southey Country}

Joanna E. Taylor

University of Manchester

\begin{abstract}
This article explores how Keswick, a market town in the northern Lake District, became the locus for Southey's development of his own poetic landscape. In particular, it argues that Southey's representations of Keswick - the most significant tourist destination in the Romantic-era Lake District - counterpointed the development in the south Lakes of Wordsworthshire, the area around Grasmere and Ambleside that Wordsworth was explicitly claiming as his poetic ground. But, this article suggests, whereas the cultural-geographical legacies of Wordsworthshire were based on texts that advocated what Keats termed the "egotistical sublime," Southey Country prioritised social interaction. This article explores how Southey's Lake District was based on texts that emphasised bonds between family and friends that were firmly tied to key locations, particularly his home at Greta Hall and the waterfall at Lodore. In doing so, this article posits a new reading of Lakeland Romanticism that situates this Lake Poet at the centre of a trans-historical community.
\end{abstract}

\section{Biographical Note}

Joanna E. Taylor is Presidential Academic Fellow in Digital Humanities at the University of Manchester; she was formerly the Senior Research Associate on the Leverhulme Trust-funded project Geospatial Innovation in the Digital Humanities: A Deep Map of the English Lake District at Lancaster University. Her research interests include literary geographies, environmental histories, and historical and digital cartographies. She is on the editorial board of The Byron Journal and is the editor of the British Association for Victorian Studies Newsletter. 


\section{Romanticism on the Net \#68-69 (Spring-Fall 2017). Special issue on Robert Southey. Guest-edited by Tim Fulford (De Montfort University) and Matthew Sangster (University of Glasgow)}

1. When Robert Southey arrived at the Coleridges' home at Greta Hall, Keswick, in September 1803, he came "with no plan of settling" (CLRS 838). He remained for forty years until his death in 1843, an overstay that comfortably beats any of the prolonged visits for which Coleridge is infamous. After Southey determined to settle there permanently in 1807, Greta Hall became home to a multiplying assortment of "books \& ... bairns" (CLRS 2146); he declared that a house was "never perfectly furnished for enjoyment, unless there is a child in it rising three years old, and a kitten rising six weeks" (Doctor 328). The household at Greta Hall had both almost perpetually between 1806 and 1822. Every spring and summer, Southey also welcomed streams of friends and visitors, or "Lakers" as he termed them (a reference to James Plumptre's satirical play of the same name). Although he complained-sometimes with mock irritation, on other occasions with genuine vexation - of the "grievous consumption of good time" (CLRS 1972) such hospitality necessitated, Southey's letters, poetry, and prose reveal how much he enjoyed Greta Hall's status as the nexus for his domestic and social circle.

2. Within weeks of arriving in Keswick, Southey was looking forward to introducing his friends to his favourite haunts: he promised John May, for instance, that he would take him to "the Lake [Derwentwater], and up Skiddaw, and along the river Greta, and to Lodore" (CLRS 841). Southey's writing about these places confirmed him as a Lake Poet who sought to create an alternative mode to Wordsworth. If the area around Grasmere, Rydal, and Ambleside was Wordsworthshire (Donaldson 2015), Derwentwater, Skiddaw, the Greta, and Lodore might be considered the boundaries of Southey Country. What I want to suggest here, though, is that Southey Country was different not only in its location, but also in the ways that individuals within it were situated imaginatively in relation to the landscape. While Wordsworth's bestknown poems imagine him wandering "lonely as a cloud" around Grasmere, Southey's works tend to guide his reader around Keswick and its environs, highlighting trans-historical interactions between individuals, communities and place as he did so. 

Tim Fulford (De Montfort University) and Matthew Sangster (University of Glasgow)

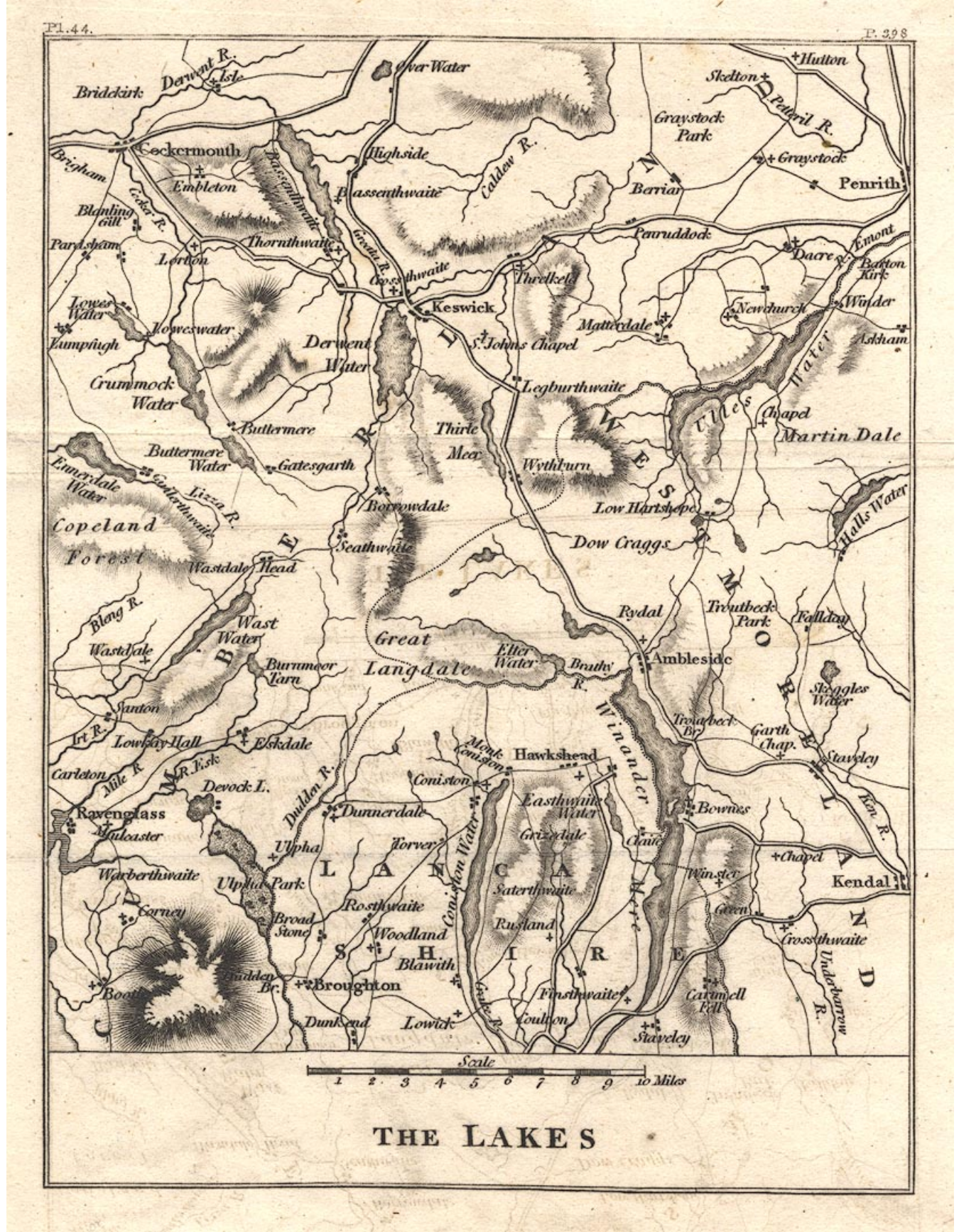

Figure 1: A map of the Lakes in 1803, the year Southey moved to Keswick, probably by John Feltham (Norgate and Norgate, 2016)

This article contributes to the re-evaluations of Southey undertaken in recent years, most notably and effectively by Carol Bolton, Tim Fulford, Ian Packer, and Lynda Pratt, all of whose work has revealed Southey to be an important Romantic poet of under-appreciated complexity. Building on these scholars' work, I argue here that paying attention to Southey's affective 


\section{Romanticism on the Net \#68-69 (Spring-Fall 2017). Special issue on Robert Southey. Guest-edited by Tim Fulford (De Montfort University) and Matthew Sangster (University of Glasgow)}

responses to the Keswick landscape goes some way towards rescuing Southey from the imputation, begun by Byron and propagated through generations of Romantic scholarship, as being little more than a dull, proto-Victorian conservative who "soar[ed] too high" in his poetic ambitions (Byron 23). More than that, though, I want to suggest that paying more attention to Southeyan ecologies offers an alternative way of reading Romanticism itself.

3. Southey did not openly publish about the Lake District until 1815, but Keswick began to infiltrate his writing shortly after his arrival (Fulford, Late Poetry 33). Southey's correspondence frequently describes goings-on in the town, and takes evident pleasure in recalling to the recipients excursions to Southey's favourite places and, as we will see, offers a test-bed for Southey's Lake poetry. His first publication about the Lake District was anonymous, and was undertaken expressly to stimulate the sense of dwelling he was impatient for; as he explained to John Rickman in December 1804, "I mean to make another attempt at settling by writing an anonymous book purporting to be the letters of a Spaniard from England" (CLRS 1005). By the time this book, Letters from England by Don Manuel Espriella, was in print in 1807, Edith and Southey had their first son, Herbert, and Southey was settled in Greta Hall.

4. By the late Romantic period, Southey had a similar - if less extreme-effect on Keswick's tourism to that which Wordsworth had on Grasmere's (Gill 2001; Yoshikawa 2014). Travel narratives and tourist guides quoted extensively from the Lake District's poets, and in Keswick Southey dominated the literary touristic market (Hess 78). The young Ruskin's excitement at the chance to get a glimpse of Southey at church is indicative of the pull that Southey's presence had (Iteriad 59; II 278-282). Keswick was at the centre of Southey Country, and locations in and around the town were presented in Southey's writing as extensions of home. I concentrate here on two places - Greta Hall and the waterfall at Lodore - to demonstrate that Southey's favourite locations offered focal points for the "intergenerational communitas between the living, the dead, and those yet to be born," that Katey Castellano has suggested was central to the ecologies of Romantic conservatism (6).

5. My central claim, in short, is that what I recognise as Southey's bioregionalism provides an alternative to the Wordsworthian individualism that, as Ralph Pite astutely notes, has 


\section{Romanticism on the Net \#68-69 (Spring-Fall 2017). Special issue on Robert Southey. Guest-edited by Tim Fulford (De Montfort University) and Matthew Sangster (University of Glasgow)}

"encouraged us to locate the Romantic in texts which are direct rather than rhetorically complex, serious more than playful, and concerned with intense, solitary experiences." Yet, as Pite goes on to suggest, it is in playful texts' emphasis on sociability that the Romantics were at their "most profoundly ecological" (145). I want to demonstrate that Southey's previous neglect by Romantic ecocriticism has resulted in a restricted view of nineteenth-century ecologies that does not reflect the complex range of imaginative responses to nature, and humanity's relationship to it, that were actually on display in this period.

\section{Romantic ecologies and affective bioregionalism}

6. The root of ecology, oikos (meaning "household" or "dwelling place") indicates the importance of home to the connection between humanity and the natural world (Snyder 33). Specifically, oikos refers to the management of and mastery over the house which, as Kevin Hutchings has argued, "suggests an anthropocentric management of, or human mastery over" the physical world when it is extrapolated to refer to "the larger realm of nature" (177). Hutchings proposes that "an alternative way of conceptualizing the ecological condition might be in terms of a complex interrelationship between "ecology's' constitutive roots oikos and logos," rather than in terms of an "oppositional limit marking an impassable boundary dividing them"; after all, he notes, "the original meaning of 'logos' is 'relation"” (189). When understood in this dialogic way, an ecology "names the universal human manner of being in the world" (Harrison 200201).

7. Although Romanticism has emerged as a field-defining area in ecocritical scholarship, Romantic ecocriticism has often run the risk of obscuring this relational concept in favour of readings that privilege the "reverie [and] solitude" that Jonathan Bate identifies as being characteristic of the Wordsworthian ecopoet (42). Scholars who have followed this interpretation have tended to assume that ecocriticism's broadest aim - to study the relationship between the human and the non-human - should focus on the relationship between the individual and the natural world (Glotfelty xviii; Cervelli 42). Often, that has meant either, as Vince Carducci summarises, "putting nature on a pedestal" and "casting it as the pristine other of modern civilisation and of the autonomous individual self" (633); or the related reduction of nature to "environment," a term which, as Bate explains, "presupposes an image of man at the 


\section{Romanticism on the Net \#68-69 (Spring-Fall 2017). Special issue on Robert Southey. Guest-edited by Tim Fulford (De Montfort University) and Matthew Sangster (University of Glasgow)}

centre, surrounded by things" (107). Such assumptions significantly detract from the "critical analysis of the term 'human' itself', which Greg Garrard has proposed is essential to ecocriticism (5).

8. Tom Lynch et al. offer an alternative: they suggest that bioregional criticism might restore the balance between human or cultural and natural or biological elements of global ecologies. They explain that, although "bioregional criticism clearly shares ecocriticism's general goals," its focus is "more narrow, concentrating on how literary works relate to specific bioregions or contribute to bioregional practice and imagination" (16). Their interpretation builds on Stephen Frenkel's suggestion that bioregionalism should be concerned with "developing communities integrated with ecosystems" (289). Although bioregionalism complements national and international efforts, its focus is extremely local; bioregionalists ask what the implications are of living in a certain area or district, rather than focusing on entire towns, counties, or countries. As Lynch et al. conclude, this shift in perspective from the global to the local "can have a major and ecologically positive influence on how we choose to relate to the world around us and, indeed, for who we imagine ourselves to be" (4). In Southey's case, a bioregional reading that focuses on Keswick and its surroundings rather than the whole Lake District can uncover the importance of located interaction in Romantic-era thinking. Further, this approach can reveal the importance of trans-historical, as well as geographical, networks that create communities across time as well as space to indicate the significance of the local present to the (inter)national past and future.

9. At its worst, this approach might run the risk of promoting parochialism. Edmund Burke, for instance, believed that such inward-looking localism resulted in the formation of "little platoon[s]" that divided society into a series of "selfish" communities. We will see that Southey's Lakeland writing toys with his community's potential insularity, but ultimately agrees with Burke that these little platoons can also offer "the first link in the series by which we proceed towards a love to our country, and to mankind" (Burke 68-69). Southey's bioregionalism foregrounds the fellowship, common endeavour, and community spirit that are integral to ecology's philological roots (Taplin 26). As Heidi C. M. Scott puts it, this kind of "microcosm" can "capture the essence of larger biospheres and the individual experience within the community circle" (140). By emphasising the sense of dwelling, or what we have seen 


\section{Romanticism on the Net \#68-69 (Spring-Fall 2017). Special issue on Robert Southey. Guest-edited by Tim Fulford (De Montfort University) and Matthew Sangster (University of Glasgow)}

Southey call "settling," bioregionalism draws out the role of the community — particularly, as I want to show here, the family — as the driving force behind the interrelation of the human and the natural.

10. Bioregionalism's emphasis on dwelling encourages what Garrard terms a self-conscious "reinhabitation" (118); that is, it promotes the repetitious (re-)discovery of somewhere that occurs when a person self-consciously re-evaluates a place they already live. As Garrard explains, dwelling "is not a transient state; rather, it implies the long-term imbrication of humans in a landscape of memory, ancestry and death, of ritual, life and work" (108). Bioregionalism, then, depends on the "long term imbrication" of personal meaning at certain sites. Coleridge believed that this kind of repetition stimulated what we might now recognise as an affective response: "we love an object," he explained, "if, as often as we see or recollect it, an agreeable sensation arises in our minds" (Lectures 45). This "sensation" is different from emotion; it is a version of what Mary Favret would recognise as "undifferentiated intensity," or affect (War 80). Favret agrees with Brian Massumi that affect is autonomic, and thus differs from emotion because it is not "owned and recognised" (Massumi 28). As Coleridge's remark also indicates, affect goes further than emotion because it infiltrates the senses, altering embodied responses to a place, object, or situation. In bioregional terms, it is affect that facilitates the "settling" that transforms a place into a dwelling. Through affect, Robert L. Thayer Jr.'s understanding of a bioregion as a "life-place" might be understood in a two-fold way: as both a place where life is, in a biological sense, and where it happens, in a sociocultural one (3).

11. Here, I argue that affective bioregionalism offers a key to understanding Southey's Lake District writings as part of a counter-narrative to a High Romanticism that valorises the individual and solitary self. My approach differs from the kind of affective ecology Pite has discovered in Wordsworth's poems. Pite argues that texts like the "Poems founded on the Affections" reveal the poet's feeling for nature itself as the force that inspires ecological relationships (145). But, as Louise Westling writes, this "kind of subjectivity ... tends to produce an heroic masculinist gaze at feminized Nature uniquely possessed by the writer" (2). The responses in which Southey's Lakeland writings participate are family-orientated (encompassing both Southey's own family, and the historical families who shaped the area 


\section{Romanticism on the Net \#68-69 (Spring-Fall 2017). Special issue on Robert Southey. Guest-edited by Tim Fulford (De Montfort University) and Matthew Sangster (University of Glasgow)}

before them). As such, Nicholas Roe indicates that Southey's writing might offer a challenge to straightforwardly masculinist traditions (63). Instead, Southey engages with what Susan Wolfson considers a 'feminine' poetics of interaction. In doing so, his Lake District writings foreground a collective gaze that highlights each place's potential to hold multiple meanings and to reflect the particular practices of its community.

12. Once Southey had made what Fulford calls "a quiet decision to desist from Laureate poems," he was free to "celebrate an engagement with landscape that evoked family life" (Late Poetry 52). Southey's "Introduction" to William Westall's Views of the Lake and of the Vale of Keswick (1820) was the first in a series of publications that featured Keswick and its environs as their central location. Most notably, A Vision of Judgment (1821), although predominantly a "Laureate poem," begins in Southey's study; "The Cataract of Lodore" (1822) transported its readers to the waterfall at the southern end of Derwentwater; and Sir Thomas More: Or, Colloquies on the Progress and Prospects of Society (1829) used a walking tour of Keswick as the inspiration for reflections on contemporary British politics and culture. In each of these works, Southey imagines a trans-temporal community of readers and writers who might be united through affective readings of Southey's best-loved places in and around Keswick.

13. What I want to demonstrate here is that Southey's Lakeland works present affection as an affective response stimulated by the personal relationships which take place at specific sites. My particular focus is on what the biographer Edward Dowden called Southey's "frolic" modes (96): the playful letters and poetry in which Southey explored how his domestic relations affected his responses to the Lake District landscape. Both Wordsworth and Southey idealised local attachments in part to, as Fulford puts it, "reclaim Lake poetry from its critics" (Late Poetry 33). Yet, Southey's affective local histories (Wohlgemut 1) are personal narratives that foreground interactions with communities - especially his domestic circle - to emphasise his responses to people and place. Scott has indicated that an ecology of the home had to wait until the Victorian period to fully develop out of Romantic ecologies. As I want to demonstrate, though, Southey's affective bioregionalism combined Romantic feeling with a proto-Victorian focus on home and family to generate readings of the landscape that takes affectionate interaction as its central mode. 


\section{Romanticism on the Net \#68-69 (Spring-Fall 2017). Special issue on Robert Southey. Guest-edited by Tim Fulford (De Montfort University) and Matthew Sangster (University of Glasgow)}

14. What Southey adds to the bioregional tradition is an awareness of the effect of transhistorical relationships on affective responses to place. Southey re-inscribes familiar landscapes with new meaning as he re-encounters familiar places with different groups of people or at different times. At the centre of his bioregion was the place to which Southey was most attached, because it housed the people for whom he felt the most affection: the Southey (and Coleridge) family home at Greta Hall.

\section{The "cosy world" at the "Aunt Hill"}

15. In Letters from England, Southey's first published - though anonymous - account of Keswick, the protagonist Espriella describes with relish his first view of the valley. After a five-hour walk from Penrith, he and his companion are especially delighted to see "the vale below us with its lake and town, girt round with mountains even more varied in their outline, and more remarkably grouped, than any which we had left behind” (262). In fact, according to Thayer's definition, Keswick is the archetypal bioregion: it is a "unique region" defined by natural boundaries that supports - and certainly supported in the Romantic period-a human community that was shaped by the region's distinctive topography (3). The landscape provided much of Keswick's employment, especially in the lead mines. More than that, Espriella indicates that affective responses to the region must influence the residents' quotidian experiences. When he has been there for a few days, Espriella finds that his initial delight can ably withstand repetition, and that witnessing the same views multiple times only improves them:

I have sometimes been satiated with works of art; a collection of pictures fatigues me, and I have regarded them at last rather as a task than as a pleasure. Here, on the contrary, the repetition of such scenes as these heightens the enjoyment of them. Every thing grows upon me. I become daily more and more sensible of the heights of the mountains, observe their forms with a more discriminating eye, and watch with increased pleasure the wonderful changes they assume under the effect of clouds or of sunshine (LFE 263).

Espriella proves himself to be the kind of attentive tourist that both Wordsworth and Southey attempted to encourage (Late Poetry 61). The more he sees the same scenes, the more details he 


\section{Romanticism on the Net \#68-69 (Spring-Fall 2017). Special issue on Robert Southey. Guest-edited by Tim Fulford (De Montfort University) and Matthew Sangster (University of Glasgow)}

notices about them. It is precisely this kind of attention to detail that, as Southey himself had discovered, transformed a bioregion into an affective zone.

16. Espriella's tour is indicative of the fact that, by the Romantic period, Keswick had become what Southey called "the proper head quarters for seeing this part of the country" (CLRS 2280). Every spring and summer it was overrun with tourists keen to partake in the picturesque scenery for which it was particularly known. The rapid growth of Keswick's tourist industry over the long nineteenth century (Denyer 3-29) indicates that an increasing number of visitors agreed with Southey that a person "cannot travel to a more beautiful place" than this rural market town (CLRS 2130). Its popularity had its drawbacks: as well as the congestion and overcrowding these visitors induced, they also initiated several cultural changes, including to fashion, dialect, and recreation. Southey slyly complained to the poet and artist Matilda Betham in 1808 that the local manufactories "furnish fine cloaths to the one sex and bad habits to the other;" he thought it a good thing that "the white sheet has been disused, - for otherwise clean sheets would be sometimes wanting in Keswick" (CLRS 1509). These indecencies seemed to get more public as time went on; by 1811, Southey was reporting to John Spedding that several publicans had taken to keeping "their houses open much later than they should be suffered to do," resulting in “outrages which almost every night [are committed] in the town" (CLRS 1889). These changes to Keswick's society impacted on Southey's responses to the area: in both Letters from England and the Colloquies, he records the damaging effects of moral laxity-alongside poor social care - on the town's life. Greta Hall, situated just outside of Keswick, offered a respite from these social woes, as well as a site from which Southey could reflect on the implications of these changes to the region. 


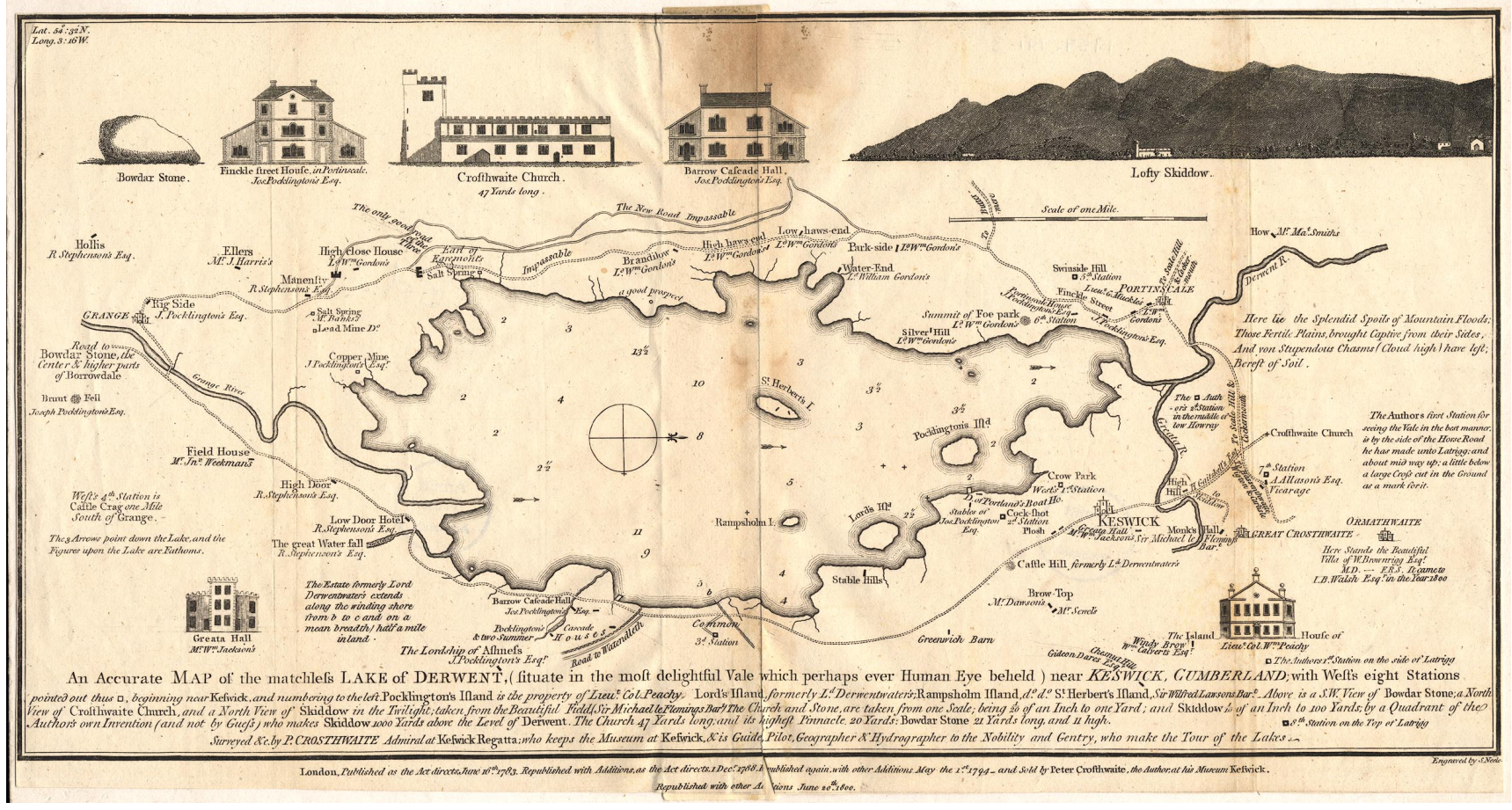

Figure 2: Peter Crosthwaite's map of Keswick (1783), showing Greta Hall alongside the town's other important residences and geographical features (Norgate and Norgate 2016).

17. Greta Hall had been built by a local businessman, William Jackson, in the late eighteenth century; it was certainly finished by 1783 , when it was included on a map of the town drawn by Peter Crosthwaite, Jackson's cousin and a friend of the Coleridge-Fricker-Southey family. As Southey explained to Betham, it comprised "two houses under one roof;" Southey and his extended family rented the larger part from Jackson, who lived in the other half. The river Greta flowed past the house "at the foot of [the] orchard," and the mountain, Skiddaw, "reache[d] within half a mile of us" (CLRS 1509). In an article for the Gentleman's Magazine in December 1805, Benjamin Travers - who would later become a famous eye-surgeon-described his first sight of Greta Hall:

As we crossed the rapid tide of the river Greeta [sic], we observed, at the distance of a stone's throw from the road, an old embattled brick mansion, apparently an uninhabited ruin; in this however we were mistaken; it was the Villa Lucretilis of one among the most celebrated of that Corpusculum Poetarum, who, it cannot be denied, have afforded abundant specimens of the exuberance of genius. His lyric brother occupies a cottage on the banks of Grasmere, for which, as his landlord assured us, he pays an annual rent of 51. - Sic itur ad astra! (qtd. in Chandler 36) 


\section{Romanticism on the Net \#68-69 (Spring-Fall 2017). Special issue on Robert Southey. Guest-edited by Tim Fulford (De Montfort University) and Matthew Sangster (University of Glasgow)}

David Chandler has suggested that Travers's identification of a body of poets associated with the Lake District anticipated Francis Jeffrey's more famous recognition of a Lake School (36). Like Jeffrey, Travers wittily juxtaposes the Lake Poets'-specifically here Southey and Wordsworth - lyricism and their quotidian needs; as the Virgilian epigram suggests, they might aim for the stars, but their earthly dwellings are something less than heavenly. Greta Hall's apparently ruinous state acts here as a synecdoche for the state of the Lake School as underrecognised "specimens of the exuberance of genius." Like the Lake Poets, the house appears to be being absorbed into the landscape to the detriment of its reputation. In fact, Travers's misreading of Greta Hall is indicative of contemporary understandings of the Lake Poets' influence more generally. As works like 'A Vision of Judgement' and Colloquies indicate, Southey disagreed with such readings; instead, works like these maintained that, although the Lake Poets appeared to have been absorbed by, and concealed in, this remote part of northern England, Southey at least remained an important commentator for both local and national concerns.

18. Greta Hall was also more prominent than Travers's interpretation allowed. Crosthwaite's map indicates the important role Greta Hall quickly assumed in late-eighteenth century Keswick. Julia S. Carlson has shown that Crosthwaite's maps "mark a confluence of late eighteenthcentury impulses toward the natural world" in the way they combined "scientific, aesthetic, commercial, and ideological interests" as inherent to the geography of the major lakes (40). In doing so, Crosthwaite's maps indicate how the cultural identity of each location depended upon the imbrication of a place's geographic and social data. On the map of Derwentwater, Greta Hall is central in both a geographic and socio-cultural sense; it features as a key site near to the lakeside, and as part of a complex network of the homes of Keswick's notaries. The house itself was a hub for Southey's extensive network, including poets, politicians, and artists. Greta Hall became, in short, a premier destination for the who's who of Romantic Britain. Southey delighted in including his visitors in his active involvement with town life; indeed, his engagement with Keswick added to Greta Hall's status as an important site for the local community, which Crosthwaite's earlier map had indicated.

19. Southey's openly professed attachment to home differed markedly from his contemporaries; only Wordsworth shared what Southey called an "inclination" to cling "obstinately to the 


\section{Romanticism on the Net \#68-69 (Spring-Fall 2017). Special issue on Robert Southey. Guest-edited by Tim Fulford (De Montfort University) and Matthew Sangster (University of Glasgow)}

hearthstone" (CLRS 841). Roe identifies Southey's need to "bring everything back home" as central to his early writings (65), and, more recently, Bolton has observed that "[t]he very real requirement for 'settling' in a home at the age of 30, after living in various locations, underpinned Southey's art" (17). Yet, the kind of domestic community Southey established at Greta Hall had been anticipated much earlier. The Pantisocracy scheme was an early-and, as James McKusick dismissively writes, "utopian (and ultimately impractical)" (36)—plan for the kind of domestic community that became crucial for Southey in both personal and professional terms. Greta Hall became, in Jean Raimond and J. R. Watson's words, a “cosy world of books, children and cats" (269) with Southey at its centre delighting in — and significantly contributing to- - the household chaos.

20. Southey and his wife, Edith, presided over a large extended family at Greta Hall. The "bairns" continued to arrive regularly until 1819. There were eight in total, including Margaret (180203), Emma (1808-09) and Herbert (1806-16). Like the child in "We Are Seven," although only four of his children survived into adulthood, Southey continued to recognise all of them as members of his household (Dowden 96). Greta Hall was also home to Edith's sister and Coleridge's wife Sarah, their three children (Hartley, Derwent, and Sara), as well as, infrequently, Coleridge himself. In addition, Southey's other sister-in-law Mary Lovell, her son Robert, the housekeeper Mrs. Wilson and, for a time, the landlord Mr. Jackson, along with servant girls, Dapper the dog, and a pounce of cats were all, at various times, in residence. Katie Waldegrave thinks that the names of the cats "give some idea of [the family's] imagination and the books which created it": Madame Bianchi, Ovid, Virgil, Pulchesia, Rumpelstiltskin, Lord Nelson, and Hurleyburleybum embodied the playfulness encouraged at Greta Hall (10). The children benefited from the intellectual prowess of their parents and guardians; Sarah Fricker Coleridge described a busy schedule at Greta Hall that included "[r]eading, writing, walking, teaching, messing, [and] mountaineering” (qtd. in Griggs 77). Her account indicates that in Southey's household, as in Wordsworth's, writing was an outdoor activity as much as an indoor one.

21. The "Aunt Hill" - as the children called it on account of the number of Fricker sisters living there - was to Southey what Dove Cottage was for the Wordsworths; in Kenneth Cervelli's words about the home at Grasmere, Greta Hall was "[m]ore than a simple domestic space" (52). 


\section{Romanticism on the Net \#68-69 (Spring-Fall 2017). Special issue on Robert Southey. Guest-edited by Tim Fulford (De Montfort University) and Matthew Sangster (University of Glasgow)}

It was the site from which Southey considered Keswick's place in the national system, and explored the lakes, streams, and mountains that surrounded it. More than that, it was a microcosm for the natural and social ecologies he found in the town and the wider world. The "great map" that hung on the wall of the landing encouraged Southey to dream about the places to which he might travel (CLRS 1540), but was indicative, too, of Greta Hall's position at the centre of an affective local bioregion that also operated as part of a global ecology.

22. The heart of the house was also the room with the most impressive view. The fact that this room, Southey's study, also doubled up as the drawing room when the family had company (Sara Coleridge 42) indicates how closely Southey's literary practices were bound up with both his family life and the Lakeland landscape. The room had two main charms for Southey. First, it seemed to "have the rare property of making all persons feel comfortably who come into it" (CLRS 1509). Second, the large window offered an unparalleled view of the surrounding mountains. Southey thought the view from the window "the finest imaginable": from it, he could see Derwentwater, Borrowdale, Newlands, the river Greta, the Vale of Keswick, and Bassenthwaite. "[A]fter rain," Lodore was visible at the other end of the Lake (CLRS 1509). Southey's detailed description of this view at the beginning of $A$ Vision of Judgement indicates how this local scene influenced the way he thought about national events:

'Twas at that sober hour when the light of day is receding,

And from surrounding things the hues where with day has adorn'd them

Fade, like the hopes of youth, till the beauty of earth is departed:

Pensive, though not in thought, I stood at the window, beholding

Mountain and lake and vale; the valley disrobed of its verdure;

Derwent retaining yet from eve a glassy reflection

Where his expanded breast, then still and smooth as a mirror,

Under the woods reposed; the hills that, calm and majestic,

Lifted their heads in the silent sky, from far Glaramara

Bleacrag, and Maidenmawr, to Grizedal and westermost Withop.

Dark and distinct they rose. The clouds had gather'd above them

High in the middle air, huge, purple, pillowy masses,

While in the west beyond was the last pale tint of the twilight;

Green as a stream in the glen whose pure and chrysolite waters

http://ronjournal.org 


\section{Romanticism on the Net \#68-69 (Spring-Fall 2017). Special issue on Robert Southey. Guest-edited by Tim Fulford (De Montfort University) and Matthew Sangster (University of Glasgow)}

Flow o'er a schistous bed, and serene as the age of the righteous.

Earth was hush'd and still; all motion and sound were suspended:

Neither man was heard, bird, beast, nor humming of insect,

Only the voice of the Greta, heard only when all is in stillness (II 1-18)

Southey's early biographer Charles T. Browne appears to have had this stanza in mind when he wrote that " $[\mathrm{t}]$ he grand and beautiful in nature were not only recreations for [Southey's] mindthey were feasts upon which his imagination could feed" (122). This stanza reveals the Keswick landscape to be much more than a series of "pretty view[s]"; as Fulford recognises, in Southey's writing "local attachment" became an "implicitly political" articulation of his conservatism (Late Poetry 33, 45). The stillness the speaker recognises in the mountains conversely reminds him of the national political clamour, and offers a metaphor for the poet's own calm steadfastness in the face of national uncertainties. Bolton perceptively comments that Espriella "brings the novelty of fresh eyes to what was for Southey a familiar sight" (52), but the speaker here has a different motivation: he highlights his intimate knowledge of the landscape in an almost Wordsworthian fashion, providing a form of verbal cartography that carefully situates him at the landscape's centre.

23. The opening of $A$ Vision of Judgement is an articulation of the "fondness" for home that Browne thought "acted upon [Southey's] spirit with a centripetal force" (121), and which stimulated Southey's representation of Keswick as a deeply affecting, and affective, bioregion. His other Lake District writing is even more focused on local geographical features as extensions of the domestic felicity he enjoyed at Greta Hall. In the Colloquies, Southey echoed Coleridge's "Frost at Midnight" in expressing his gratitude that he was able to witness his children's enjoyment at growing up in "a country such as Cumberland" (119), and the children were particularly important for Southey's development of a literary response to Keswick that explored it both as a beautiful place, and as a container for his deep affection for his family.

\section{III. "Laureate / To them": Re-creating Lodore}

24. The waterfall at Lodore was the destination for regular family excursions and, in his writing about it, Southey foregrounded the development of an affective sense of place that emerged from an interplay between the location and his family's relationship to it. Southey's engagement 


\section{Romanticism on the Net \#68-69 (Spring-Fall 2017). Special issue on Robert Southey. Guest-edited by Tim Fulford (De Montfort University) and Matthew Sangster (University of Glasgow)}

with Derwentwater and Lodore in print began in Letters from England. Espriella opines that Derwentwater "has this decided advantage over the others which we have seen, that it immediately appears to be what it is. Winandermere and Ulswater might be mistaken for great rivers, nor indeed can the whole extent of either be seen at once; here you are on a landlocked bason of water, a league in length, and about half as broad." The "pride" of this lake, according to Espriella, is at its head, "where the mountains of Borrodale bound the prospect, in a wilder and grander manner than words can adequately describe" (263). Lodore enters Derwentwater towards the head on the eastern side and, although it requires heavy rainfall to achieve the full effect, Espriella echoed Southey's opinion that it was "at once the finest work and instrument of rock and water that I have ever seen or heard" (263).

25. The walk along the eastern side of Derwentwater to the waterfall at Lodore was a firm family favourite. Southey mentions in his letters when the children were young that they had been, or were intending to go, to the waterfall regularly. Even though the tourist attractions that sprung up around Derwentwater-such as the cannon at Lodore (Bolton 56; Fulford, Late Poetry 218)_emblematised much that Southey considered wrong with the modern tourist's Lake District, Lodore became almost metonymic for Southey's love for his children, particularly his eldest son Herbert, and for his attachment to the landscape in which they grew up.

26. Herbert was named after Southey's uncle, but it was a name that was also peculiarly appropriate for a child born at Keswick. The ruins of a cell and oratory built by Saint Herbert, a hermit who lived on an island in the middle of Derwentwater in the seventh century, continued to be one of Keswick's most myth-laden sites. When Herbert died in April 1816, Southey's first response was to write that he would "remove from Cumberland" (CLRS 2760) as soon as his lease on Greta Hall expired. His sudden eagerness to leave indicates how deeply his affective responses to Keswick were wrapped up with his love for the child (and vice-versa). When Southey's second son was born in 1819, he was named with a nod to both the Lake District's folkloric history and to his older brother. In public, Southey maintained that Cuthbert was so called because his father "like[d] genuine English names, \& such as are peculiar without being fantastic." He confided to Grosvenor Bedford, though, that the "secret feeling" behind Cuthbert's name was an act of memorial for Herbert (CLRS 3255); Saint Cuthbert was the "beloved friend" of Saint Herbert, and, so the legend goes, "Those holy Men both died in the 


\section{Romanticism on the Net \#68-69 (Spring-Fall 2017). Special issue on Robert Southey. Guest-edited by Tim Fulford (De Montfort University) and Matthew Sangster (University of Glasgow)}

same hour" (Wordsworth, "Inscriptions," 1. 27), an expression of the deepest sort of brotherly feeling.

27. Although Derwentwater and St Herbert's Isle continued to remind Southey of Herbert, it was Lodore that he associated particularly with his son. In March 1815, Southey wrote proudly to Bedford that the nine-year-old had written an "Ode to Lodore," which "makes Mrs Wilson say 'he'll beat all you poets"' (though Southey also notes that Herbert's "notion of an Ode is about as correct as it is of the Milky Way") (CLRS 2565). This "Ode" has not been preserved, but it was, perhaps, composed in conversation with a poem Southey had been working on for several years: "The Cataract of Lodore." This poem is first mentioned in a letter to Thomas Southey from October 1809, the composition of which indicates that Herbert was already linked, in Southey's mind, with the poem and the waterfall:

My dear Tom

I forgot to answer your question about Herberts [sic] feet,- - he has quite out grown the defect, whatever it was, \& walks as well as can be. You know my ingenuity for inventing causes for kissing, - I have lately struck out one in addition to all the others which I hope will meet your approbation,- - after the Fathership \& Son ship \& all the other ships have been exhausted, there now comes a kiss for that good Ship the Dreadnought where Uncle Tom lives. I hope also you will approve of a description of the water at Lodore, made originally for Edith \& greatly admired by Herbert. in my mind it surpasses any that the Tourists have yet printed. Thus it runs-"Tell the people how the water comes down at Lodore!-Why it comes thundering \& floundering, \& thumping \& flumping \& bumping \& jumping, \& hissing \& whizzing, $\&$ dripping \& skipping, \& grumbling \& rumbling $<\&$ tumbling $>$, \& falling \& brawling, \& dashing $<\&$ clashing $>\&$ splashing, \& pouring \& roaring, \& whirling \& curling, \& leaping \& creeping, \& sounding \& bounding, \& clattering \& shattering, with a dreadful uproar, — \& that way the water comes down at Lodore" (CLRS 1696).

Southey's discussion of Herbert's feet flows into his presentation of a fleet-footed metre that mimics the waterfall's movement, blending Herbert's physical experiences with the family's metrical games. Southey's gently ironic suggestion that the poem was "greatly admired" by the infants anticipates the tone of self-mockery that Fulford has argued was implicit in Southey's declaration, when a much-expanded version of the poem was printed, that it was written by a 


\section{Romanticism on the Net \#68-69 (Spring-Fall 2017). Special issue on Robert Southey. Guest-edited by Tim Fulford (De Montfort University) and Matthew Sangster (University of Glasgow)}

Lake Poet; Southey, Fulford says, "embrac[ed] the pejorative label that critics had applied to verse they called puerile and childish" (52-53). In this letter, Southey presents the poem as evidence of a deeply affectionate relationship between Southey, his infant children, and the landscape in which they were growing up. For Southey, this specifically located affection became a powerful creative force. The "Cataract of Lodore" was the most convincing expression of Southey's affective bioregionalism, which he communicated by adapting the place's rhythms into poetic movements.

28. The later poem expanded on the onomatopoeic exuberance evidenced in the letter. As Susan Wolfson puts it, the poem is Southey's jeu d'esprit, "a poem shaped, phonically and metrically, into a cascade of sounds that not only coincide with lexical sense but drive it as a primary expressive force" ("Sounding Romantic"). It is written in what one later writer called "dithyrambics, playful and irregular as [Lodore's] waters" (Keswick 28); the words imitate in lively ways the sounds of the water as it comes over the rocks. Perhaps more evidently than any other Romantic poem, "The Cataract of Lodore" re-inscribes itself "onto the landscape to which it points" ("Materialization" 15): by claiming the name of the waterfall for the poem as well, it offers a cartographic textual portrait of the cataract.

29. The poem offers a reading of the waterfall at Lodore that was distinct from Wordsworth's dismissal of it as a simple "roar" ("An Evening Walk" 1.5). The poem investigates the transformation by attentive listening of a waterfall's "deafening noise" into a complex musical — and metrical—sound. Like in the letter, the later versions of Southey's poem present it as the result of a creative conversation between Southey and his children, especially Herbert. The way the early version opens with an exclamation ("Tell the people how the water comes down at Lodore!") indicates that the infant audience are only listeners. The later versions, though, posit them as agents who inspire and contribute to Southey's literary project. One version begins:

"How does the water

Come down at Lodore?"

My little boy asked me

Thus, once on a time;

And moreover he tasked me 


\section{Romanticism on the Net \#68-69 (Spring-Fall 2017). Special issue on Robert Southey. Guest-edited by Tim Fulford (De Montfort University) and Matthew Sangster (University of Glasgow)}

To tell him in rhyme.

Anon, at the word,

There first came one daughter,

And then came another,

To second and third

The request of their brother,

And to hear how the water

Comes down at Lodore,

With its rush and its roar,

As many a time

They had seen it before.

So I told them in rhyme,

For of rhymes I had store;

And 'twas in my vocation

For their recreation

That so I should sing;

Because I was Laureate

To them and the King. (11.1-23)

The poem's tone recalls Wordsworth's "Anecdote for Fathers," where another "little boy" is in conversation with a parental figure. In Wordsworth's poem, the boy finds himself unable to answer-truthfully, at least - the father's insistent questioning. Southey's poem reverses the flow of the conversation, and uses the children's question as a creative stimulus. Indeed, the speaker confesses that his "vocation" is - in part at least-designed for the children's "recreation." That Southey is the nation's "Laureate" is less important here than the fact that he is also his children's "Laureate." In this poem, Southey's local attachment to his children and home precedes his commitment to the King and nation.

30. The poem proceeds to offer another form of "re-creation": it aims to mimic the experience, familiar to Southey's children, of being at Lodore. When it was published in Joanna Baillie's anthology Poems, Chiefly Manuscript, and from Living Authors in 1823, Baillie wrote to Southey to say how the poem had "pleased and amused her," and she predicted that "the younger part of my readers [will be] running about with portions of it in their mouths and 


\section{Romanticism on the Net \#68-69 (Spring-Fall 2017). Special issue on Robert Southey. Guest-edited by Tim Fulford (De Montfort University) and Matthew Sangster (University of Glasgow)}

shaking their heads to the measure, for these six months to come" (Baillie, Letters 27). The poem thus operates differently to Wordsworth's Lakeland verse. Wordsworth's poetry suggests, in Martin Ryle's words, that "a capacity to love and learn from nature is a special rather than a general disposition" (14). Verses such as "Poems on the Naming of Places" share the poet's personal version of the landscape with the reader; locations like Emma's Dell or Joanna's Rock are re-named to emphasise the Wordsworth family's unique connections with the landscape. "The Cataract of Lodore," on the other hand, indicates that anyone can discover an affective connection with the landscape; the poem seemed to Baillie to infect young readers with Lakeland rhythms and, by extension, to instil an intimate relationship with the waterfall, even at a distance. It seemed to transpose the waterfall's physical and imaginative effects to wherever the poem was read. In this way, the poem itself becomes a synecdoche for an affective bioregion that aims to stimulate embodied and affective responses to the Lake District, even at a spatial or temporal distance. More than that, the poem enacts an alternative form of Lakeland Romanticism that democratically invites all readers to partake in this literary landscape. 
Romanticism on the Net \#68-69 (Spring-Fall 2017). Special issue on Robert Southey. Guest-edited by Tim Fulford (De Montfort University) and Matthew Sangster (University of Glasgow)

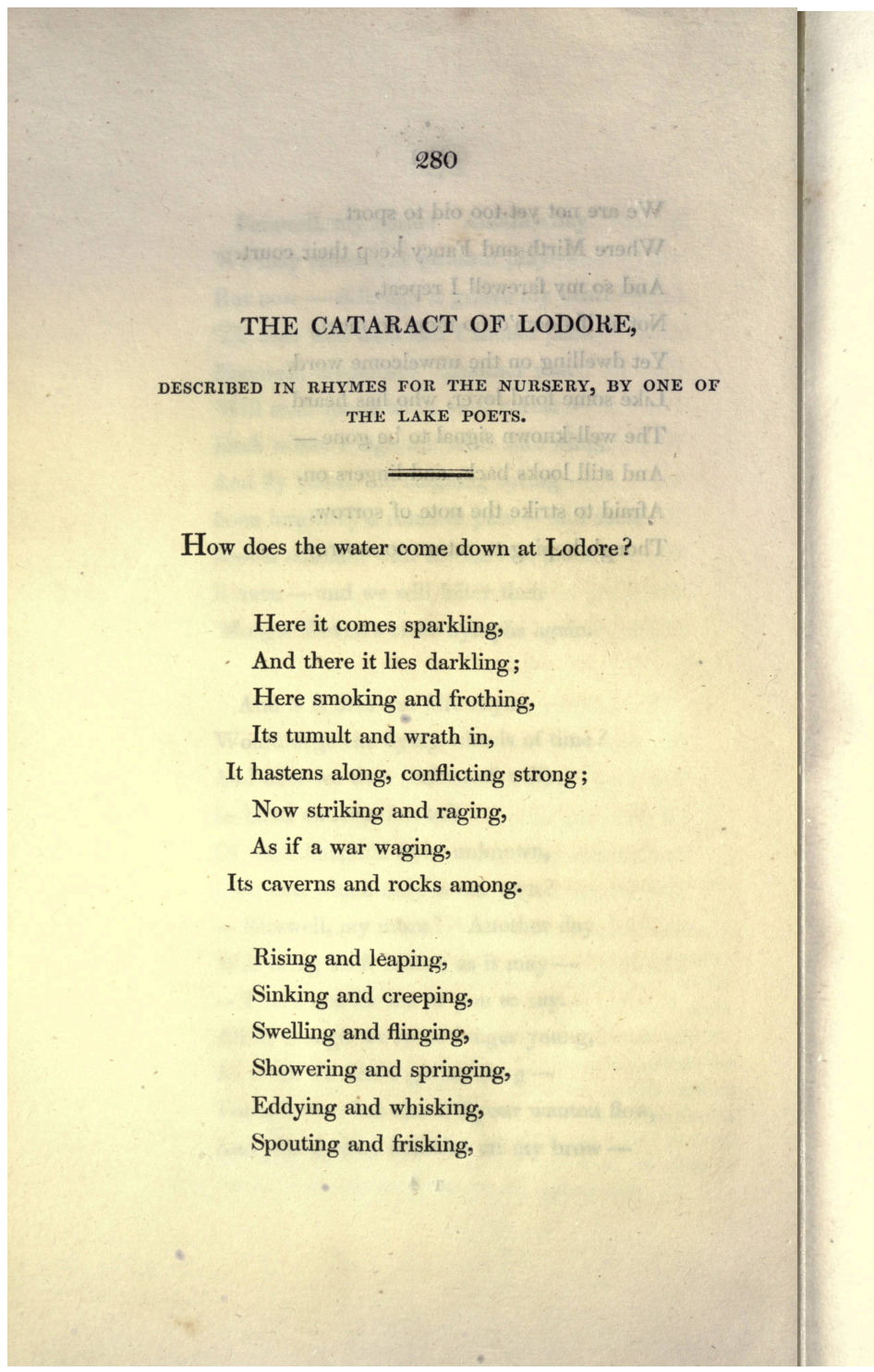

\section{1}

Turning and twisting Around and around, Collecting, disjecting With endless rebound;

Smiting and fighting, A sight to delight in,

Confounding, astounding,

Dizzying and deafening the ear with its sound.

Receding and speeding, And shocking and rocking, And darting and parting, And threading and spreading, And whizzing and hissing, And dripping and skipping, And whitening and brightening, And quivering and shivering, And hitting and splitting, And shining and twining, And rattling and battling, And shaking and quaking, And pouring and roaring, And waving and raving, And tossing and crossing, And flowing and growing, And running and stunning, 


\section{Romanticism on the Net \#68-69 (Spring-Fall 2017). Special issue on Robert Southey. Guest-edited by}

Tim Fulford (De Montfort University) and Matthew Sangster (University of Glasgow)

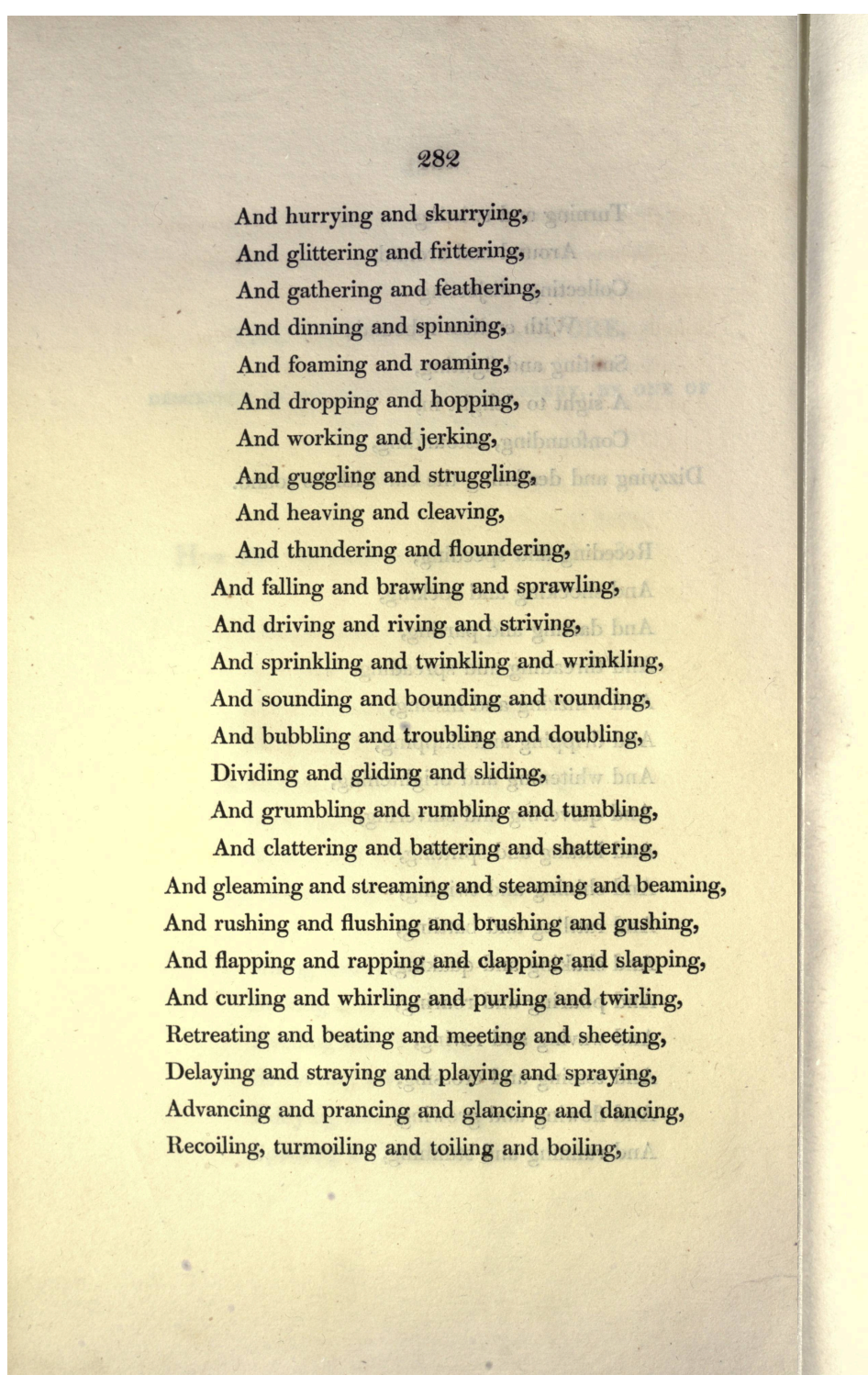

Figure 3: "The Cataract of Lodore" as it appeared in Joanna Baillie's Poems, Chiefly Manuscript, and from Living Authors (1823).

31. Although Herbert and the other children are excised from Baillie's published version, his question remains: how does the water come down? It is answered by an expanded exploration of the waterfall's physical journey, and demonstrates how its physical—and related visual— qualities are inherent to its acoustic effects. As the poem concludes, the cataract's "motions" are blended intrinsically with its "sounds" (Baillie, Poems 283; 1.70) — and that is true of the poem as well. The poem's movement encourages an affective response in the reader that asks them to imagine themselves as part of the waterfall. It begins slowly, with the waters in Watendlath 


\section{Romanticism on the Net \#68-69 (Spring-Fall 2017). Special issue on Robert Southey. Guest-edited by Tim Fulford (De Montfort University) and Matthew Sangster (University of Glasgow)}

Tarn: "its own little lake." We pause here, halted by the full stop. We wait, just like the water in the tarn, taking a breath before the plunge down the cliff-face. The poem quickens as it follows the water over the edge; it becomes a profusion of active verbs ("Rising and leaping, / Sinking and creeping, / Swelling and flinging, / Showering and springing" [Baillie, Poems 280; II.1013]) that imitate the water's rapid descent. It provides a highly specific-if not exactly accurate - map of the waterfall that imagines details down to the way that individual rocks might disrupt the flow of the water:

And glittering and frittering,

And gathering and feathering,

And dinning and spinning,

And foaming and roaming,

And dropping and hopping,

And working and jerking,

And guggling and struggling,

And heaving and cleaving,

And moaning and groaning;

And thundering and floundering,

And falling and brawling and sprawling,

And driving and riving and striving,

And sprinkling and twinkling and wrinkling,

And sounding and bounding and rounding. (11. 42-54)

The movement of the water is decipherable; each line stands in for the rocks that make up the drop. The short vowel sounds that replicate the water's quick falls_- "dinning and spinning," "dropping and hopping"-lengthen as the words mimic the way that the water slows momentarily as it reaches one of the small pools that gather along the waterfall's descent. The poem, like the cataract, demands slower reading at these junctures: where the water lies "moaning and groaning" or "thundering and floundering," the poem also requires a pause. The semi-colons confirm a change of pace, before the stanza breaks imitate the next short drop.

32. As the poem follows the waterfall to the bottom, it mimics the changes in the water's movement. Syllables become consistently long, and the sound of the consonants is heavier in mimicry of the water's more lumbering flow in the lower stages of the fall: "Delaying and 


\section{Romanticism on the Net \#68-69 (Spring-Fall 2017). Special issue on Robert Southey. Guest-edited by Tim Fulford (De Montfort University) and Matthew Sangster (University of Glasgow)}

straying and playing and spraying, / Advancing and prancing and glancing and dancing" (Baillie, Poems 282; II. 64-65). Finally, the poem, with the cataract, splashes into the stream at the bottom. In short, the poem itself acts as an affective bioregion that is formed out of a series of metrical representations of the interactions between individual water droplets, between water and landscape, and between landscape and listener. Whilst Wordsworth's preference for firstperson narration privileges private knowledge of the landscape, Southey's multi-sensory account in the poem, which recreates the waterfall's acoustics in its rhythms and its appearance in the look of the print on the page, invites the reader into a communal experience. Each of these relationships emerges as essential for answering Herbert's question which, in the poem's foregrounding of these complex interrelationships, becomes profoundly ecological.

33. Reading Southey's writing as affective meditations on the role of people in place offers an opportunity to re-evaluate Romantic ecologies at the local level, whilst remaining mindful of the impact of the regional on the global. Whilst Wordsworth's writing emphasises the individual's relationship to nature, Southey's Lakeland works emphasise trans-historical relationships between people and place. These works foregrounded a playful sociability between Southey and his social circle, and between humanity and the natural world. They revealed the landscape around Keswick to be more than a simple setting for his works; the rhythms and movements of this place are translated into Southey's poetry and prose. Southey wrote in 1818 that he felt himself becoming part of the landscape, "almost as much a fixture as my great neighbour Skiddaw himself" (CLRS 3186), but his Lakeland writing reveals that this process had begun much earlier. Southey's works reveal the development of an affective bioregionalism that recognises the Lake Poet as one part of a much wider community whose habits and relationships are formed through its connection with the local landscape. 


\section{Romanticism on the Net \#68-69 (Spring-Fall 2017). Special issue on Robert Southey. Guest-edited by}

Tim Fulford (De Montfort University) and Matthew Sangster (University of Glasgow)

\section{Works Cited}

Baillie, Joanna. Collection of Poems, Chiefly Manuscript, and from Living Authors. London: Longman \& Co., 1823.

---. Further Letters of Joanna Baillie. Edited by Thomas McLean, Madison, NJ: Fairleigh Dickinson University Press, 2010. (Letters).

Bate, Jonathan. The Song of the Earth. Cambridge, MA: Harvard University Press, 2002.

Bolton, Carol. "Introduction." Letters from England, by Don Manuel Espriella, edited by Carol Bolton, London and New York: Routledge, 2016, pp. 15-79.

Browne, Charles T. Life of Robert Southey, LL.D., Poet Laureate, \& c. London: Chapman \& Hall, 1854.

Burke, Edmund. Reflections on the Revolution in France, and on the Proceedings in Certain Societies in London Relative to that Event. London: J. Dodsley, 1790.

Byron, George Gordon. The Major Works. Edited by Jerome McGann, Oxford: Oxford University Press, 1986.

Carducci, Vince. "Ecocriticism, Ecomimesis, and the Romantic Roots of Modern Ethical Consumption." Literature Compass, vol. 6, no. 3, 2009, pp. 632-646.

Carlson, Julia S. Romantic Marks and Measures: Wordsworth's Poetry in Fields of Print. Philadelphia: University of Pennsylvania Press, 2016.

Castellano, Katey. The Ecology of British Romantic Conservatism, 1790-1837. Basingstoke and New York: Palgrave Macmillan, 2013.

Cervelli, Kenneth R. Dorothy Wordsworth's Ecology. New York: Routledge, 2007.

Coleridge, Samuel Taylor. The Collected Letters of Samuel Taylor Coleridge. Vol. I. Edited by Earl Leslie Griggs, Oxford: Clarendon Press, 1956.

---. The Collected Works of Samuel Taylor Coleridge, Volume 1: Lectures, 1795: On Politics and Religion. Edited by Lewis Patton and Peter Mann, Princeton: Princeton University Press, 1971.

Coleridge, Sara. Memoir and Letters of Sara Coleridge. Edited by Edith Coleridge. New York: Harper \& Brothers, 1874.

Denyer, Susan. “The Lake District Landscape: Cultural or Natural?” The Making of a Cultural Landscape: The English Lake District as Tourist Destination, 1750-2010, edited by John K. Walton and Jason Wood, Farnham: Ashgate, 2013, pp. 3-29. 


\section{Romanticism on the Net \#68-69 (Spring-Fall 2017). Special issue on Robert Southey. Guest-edited by}

Tim Fulford (De Montfort University) and Matthew Sangster (University of Glasgow)

Donaldson, Christopher, et al. "Mapping 'Wordsworthshire': a GIS study of literary tourism in Victorian Lakeland." Journal of Victorian Culture, vol. 20, no. 3, 2015, pp. 287-307.

Dowden, Edward. Southey. Cambridge: Cambridge University Press, 2011 [first published 1879].

Favret, Mary. "The Study of Affect and Romanticism.” Literature Compass, vol. 6, no. 6, 2009, pp. 1159-1166.

---. War at a Distance: Romanticism and the Making of Modern Wartime. Princeton: Princeton University Press, 2010. (War).

Frenkel, Stephen. "Old Theories in New Places? Environmental Determinism and Bioregionalism.” Professional Geographer, vol. 46, no. 3, 1994, pp. 289-295.

Fulford, Tim. The Late Poetry of the Lake Poets: Romanticism Revised. Cambridge: Cambridge University Press, 2013. (Late Poetry).

---. "The Materialization of the Lyric and the Romantic Construction of Place: Bards and Beats on Dartmoor." Romanticism, vol. 22, no. 1, 2016, pp. 15-32.

Garrard, Greg. Ecocriticism. London and New York: Routledge, 2004.

Gill, Stephen. Wordsworth and the Victorians. Oxford: Oxford University Press, 2001.

Glotfelty, Cheryll. "Introduction." The Ecocriticism Reader: Landmarks in Literary Ecology, edited by Cheryll Glotfelty and Harold Fromm, Athens, GA: University of Georgia Press, 1996, pp. xv-Xxxvi.

Griggs, Earl Leslie. Coleridge Fille: A Biography of Sara Coleridge. Oxford: Oxford University Press, 1940.

Harrison, Robert Pogue. Forests: The Shadow of Civilization. Chicago: University of Chicago Press, 1992.

Hess, Scott. William Wordsworth and the Ecology of Authorship: The Roots of Environmentalism in Nineteenth-Century Culture. Charlottesville: University of Virginia Press, 2012.

Hutchings, Kevin. "Ecocriticism in British Romantic Studies.” Literature Compass, vol. 4, no. 1, 2007, pp. 172-202.

Keswick and its neighbourhood: A hand-book for the use of visitors, to all the scenery, nooks, and corners of the district. Windermere: John Garnett, 1852. 


\section{Romanticism on the Net \#68-69 (Spring-Fall 2017). Special issue on Robert Southey. Guest-edited by}

Tim Fulford (De Montfort University) and Matthew Sangster (University of Glasgow)

Lynch, Tom, et al.. "Introduction." The Bioregional Imagination: Literature, Ecology and Place, edited by Karla Armbruster, Ezra J. Zeitler, Tom Lynch, and Cheryll Glotfelty, Athens, GA: University of Georgia Press, 2012, pp. 1-29.

Massumi, Brian. Parables for the Virtual: Movement, Affect, Sensation. Durham, NC: Duke University Press, 2002.

McKusick, James. Green Writing: Romanticism and Ecology. New York: St. Martin's Press, 2000.

Norgate, Martin, and Jean Norgate. Guides to the Lakes. 2016, www.lakesguides.co.uk.

Pite, Ralph. "Founded on the Affections': A Romantic Ecology." The Environmental Tradition in English Literature, edited by John Parham, Aldershot: Ashgate, 2002, pp. 144-155.

Plumptre, James. The Lakers: A Comic Opera in Three Acts. London: W. Clarke, 1798.

Raimond, Jean, and J. R. Watson. A Handbook to English Romanticism. London: Macmillan, 1992.

Roe, Nicholas. The Politics of Nature: William Wordsworth and Some Contemporaries. $2^{\text {nd }}$ edition, Basingstoke: Palgrave Macmillan, 2002.

Ruskin, John. Iteriad, or Three Weeks Among the Lakes. Edited by James S. Dearden, Newcastle: Frank Graham, 1969.

Ryle, Martin. “After 'Organic Community': Ecocriticism, Nature and Human Nature." The Environmental Tradition in English Literature, edited by John Parham, Aldershot: Ashgate, 2002, pp. 11-23.

Scott, Heidi C. M. Chaos and Cosmos: Literary Roots of Modern Ecology in the British Nineteenth Century. University Park: Pennsylvania State University Press, 2014.

Snyder, Gary. "Ecology, Literature and the New World Disorder." Irish Pages, vol. 2, no. 2, 2004, pp. 19-31.

Southey, Robert. The Doctor, \&c. Vol IV, London: Longman, Rees, Orme, Brown, Green and Longman, 1837.

---. The Collected Letters of Robert Southey: A Romantic Circles Electronic Edition. General editors Lynda Pratt, Tim Fulford, and Ian Packer, University of Maryland: Romantic Circles Electronic Editions, 2009-, http://www.rc.umd.edu/editions/southey_letters. (CLRS). 


\section{Romanticism on the Net \#68-69 (Spring-Fall 2017). Special issue on Robert Southey. Guest-edited by}

Tim Fulford (De Montfort University) and Matthew Sangster (University of Glasgow)

---. Later Poetical Works, 1811-1838. Edited by Lynda Pratt, Tim Fulford, Carol Bolton, Ian Packer, Diego Saglia, Daniel E. White, and Rachel Crawford, 4 vols., London: Pickering \& Chatto, 2012. (LPW).

---. Letters from England by Don Manuel Alvarez Espriella. Edited by Carol Bolton, London and New York: Routledge, 2016. (LFE).

Taplin, Kim. Tongues in Trees: Studies in Literature \& Ecology. Bideford: Green Books, 1989.

Thayer Jr., Robert L. LifePlace: Bioregional Thought and Practice. Berkeley: University of California Press, 2003.

Waldegrave, Katie. The Poets' Daughters: Dora Wordsworth and Sara Coleridge. London: Windmill Books, 2013.

Westling, Louise. "Introduction." The Environmental Tradition in English Literature, edited by John Parham, Aldershot: Ashgate, 2002, pp. 1-8.

Wohlgemut, Esther. "Southey, Macaulay and the Idea of a Picturesque History." Romanticism and Victorianism on the Net, no. 32-33, 2003-4.

Wolfson, Susan J. Romantic Interactions: Social Being \& the Turns of Literary Action. Baltimore: Johns Hopkins University Press, 2010.

---. "Sounding Romantic: The Sound of Sound." 'Soundings of Things Done': The Poetry and Poetics of Sound in the Romantic Ear and Era, edited by Susan J. Wolfson. Romantic Circles, 2008, https://www.rc.umd.edu/praxis/ soundings/ wolfson/wolfson.html.

Wordsworth, William. Lyrical Ballads, and Other Poems, 1797-1800. Edited by James Butler and Karen Green, Ithaca, NY: Cornell University Press, 1992.

Yoshikawa, Saeko. William Wordsworth and the Invention of Tourism, 1820-1900. Farnham: Ashgate, 2014.

\section{Acknowledgments}

Research for this article was supported by the Geospatial Innovation in the Digital Humanities: A Deep Map of the English Lake District project, funded by the Leverhulme Trust (RPG-2015230). 